九州大学学術情報リポジトリ

Kyushu University Institutional Repository

Foreign Direct Investment of Japanese Firms in the Primary Sector of Asian Economies

Bai, Hu

Agricultural Economics Laboratory, Faculty of Agriculture, Kyushu University

https://doi.org/10.5109/24210

出版情報：九州大学大学院農学研究院紀要. 42 (1/2)，pp.237-247，1997-12. Kyushu University バージョン：

権利関係 : 


\title{
Foreign Direct Investment of Japanese Firms in the Primary Sector of Asian Economies
}

\author{
Hu Bai \\ Agricultural Economics Laboratory, Faculty of Agriculture \\ Kyushu University, Fukuoka 812-81, Japan \\ (Received July 30, 1997 and accepted August 25, 1997)
}

This study examined empirically the main features of foreign direct investment of Japanese private firms(JDI) in the primary sector of Asian economies, and identified the determinants affecting the direction, magnitude and regional distribution of these investment flows, by estimating a set of investment functions and analyzing firm survey data. The movement of the aggregate JDI flows is found to be influenced primarily by exchange rates, firm's financing environment, and domestic business conditions, while change in the size of investing in the primary sector is more sensitive to exchange rates and cost factors. The investment inefficiency in Europe, North America, and Oceania is covered by the higher return in Asian area, which therefore become a key factor driving the resurgence of JDI flows to Asian economies.

\section{INTRODUCTION}

In international economic activities the importance of foreign direct investment has rapidly increased since 1980 s, though the foreign trade is still playing the most important roles. Direct investment from the world increased by four times over 1980-90.

In this study, I shall confine my attention to such direct investment flows from Japanese firms to the primary sector of Asian economies, with an international comparative view. The primary sector is defined by the sum of agriculture, forestry, fisheries and food processing. Part 1 describes the trends and characteristics of JDI to the foreign primary sector, with an emphasis on Asian economies. Part 2 discusses the possible factors influencing such flows and suggests a set of JDI function models, and then these models are estimated in Part 3. Part 4 provides some prospects on the resurgence of JDI to Asia. Part 5 summarizes the results of this study.

\section{TRENDS AND CHARACTERISTICS OF JDI IN THE PRIMARY SECTOR}

\section{General Trends}

Direct investment flows from Japanese private firms to foreign countries experienced a rapid decrease during 1990-92 with the persistent recession, after having reached a peak of $\$ 67.5$ billion in 1989 . However, these investment flows have again begun to increase since 1993, and recorded a 14 percent growth in 1994 compared to the previous year.

JDI in the 1990s has shown some signs of returning to developing countries, particularly those in Asia. The share of such flows to developing countries rose steadily from 21 percent in 1990 to about 38 percent in 1994, while 66 percent of this increase was directed at Asian economies. 
Table 1. Direct Investment of Japanese Private Firms in the Foreign Primary Sector (in millions of U.S. dollars)

\begin{tabular}{lccccccc}
\hline & \multicolumn{2}{c}{ Annual average } & 1990 & 1991 & 1992 & 1993 & 1994 \\
\cline { 2 - 6 } & $1951-84$ & $85-89$ & & & & & \\
\hline Aggregate & 73 & 596 & 1033 & 980 & 747 & 1017 & 1628 \\
$\quad \begin{array}{l}\text { Agriculture, forestry } \\
\text { \& fisheries }\end{array}$ & 34 & 143 & 212 & 348 & 230 & 129 & 368 \\
$\quad \begin{array}{l}\text { Food processing } \\
\text { Regional distribution }\end{array}$ & 29 & 453 & 821 & 632 & 517 & 888 & 1260 \\
$\quad$ & 16 & 193 & 170 & 208 & 142 & 182 & 431 \\
Asia & $(26)$ & $(32)$ & $(25)$ & $(14)$ & $(30)$ & $(33)$ & $(51)$ \\
$\quad$ North America & 23 & 254 & 392 & 395 & 425 & 130 & 296 \\
Europe & 2 & 55 & 218 & 62 & 45 & 49 & 154 \\
$\quad$ Oceania & 6 & 60 & 197 & 201 & 73 & 636 & 684 \\
Others & 26 & 34 & 56 & 114 & 62 & 20 & 63 \\
\hline
\end{tabular}

Source: Japan, Ministry of Finance Statistics Monthly.

the shares of the flows to Asian agriculture, forestry, and fisheries in parentheses

JDI into the foreign primary sector grew rapidly after the mid-1980s. Although the size of such investment is still small relative to the total amount, as indicated in table 1 , the pace of growth is noticeable. The magnitude of such flows reached $\$ 1628$ million in 1994 , -an unprecedented record, after averaging $\$ 944$ million a year during the 1990-93 period.

According to the Ministry of Finance, JDI flows to foreign primary sector were only modest during 1951-70. Afterward, although the volume of these flows increased somewhat, year-to-year fluctuation continued until the early 1980s. As domestic consumption in staple food -meat, fruits, and vegetables- and of raw materials used in food processing, was supplied primarily by the domestic agricultural sector at that time, only a few firms were interested in investing abroad. However, this situation has rapidly changed since 1986 with the expansion of agricultural imports, a persistent decline of the Japanese yen against the U. S. dollar, and domestic business upturn, though a substantial decrease was experienced due to a recession after 1990. As a result, the magnitude of such investment in the last four years was above the accumulation of the past 40 years. In addition, the composition of these investments has greatly changed as the size of investments in food processing rose, which accounted for 77 percent of the total amount to the primary sector in 1994.

JDI in the primary sector shows high concentration in major recipients. Table 2 presents 10 major recipient economies and their shares respectively, which together accounted for 76 percent of the total JDI to this sector during 1951-84, 85 percent during $1985-89$, and 88 percent in the last 5 years. The most current data indicates that this trend is becoming clearer, reaching 93 percent in 1994. 
Table 2. Main Recipients of Japanese Direct Investment in the Primary Sector (ranked in order of share size)

\begin{tabular}{|c|c|c|c|c|c|c|}
\hline & \multicolumn{2}{|c|}{$1951-84$} & \multicolumn{2}{|l|}{$1985-89$} & \multicolumn{2}{|c|}{$1990-94$} \\
\hline 1 & United States & 32.6 & United States & 41.8 & United States & $29.9(18.2)$ \\
\hline 2 & Brazil & 12.3 & Singapore & 15.1 & Australia & $27.9(36.1)$ \\
\hline 3 & Indonesia & 10.4 & Australia & 8.0 & China & $5.6(8.6)$ \\
\hline 4 & Canada & 4.4 & Thai land & 3.8 & Thai land & $5.0(3.4)$ \\
\hline 5 & Australia & 4.1 & France & 3.6 & New Zealand & $4.6(5.8)$ \\
\hline 6 & Thai land & 3.4 & United Kingdom & 3.1 & Hong Kong & $4.3(9.7)$ \\
\hline 7 & Philipines & 3.0 & China & 3.0 & France & $4.2(3.7)$ \\
\hline 8 & Malaysia & 2.3 & Indonesia & 2.4 & Indonesia & $2.6(2.5)$ \\
\hline 9 & Maxico & 2.0 & South Korea & 2.1 & United Kingdom & $2.1(3.7)$ \\
\hline \multirow[t]{2}{*}{10} & South Korea & 1.9 & Hong Kong & 2.0 & Nether land & $1.9(1.0)$ \\
\hline & Sum of shares & 76.4 & & 84.9 & & $88.1(92.7)$ \\
\hline
\end{tabular}

Source: Japan, Ministry of Finance Statistics Monthly. figures for 1994 in parentheses.

\section{Resurgence of JDI flows to Asian Economies}

JDI to the foreign primary sector was once concentrated largely in some Asian countries, such as Indonesia, Thailand, and the Philippines before the mid-1970s when the size was quite modest. With the expansion of the capital flows, Japanese investors gradually shifted their emphases to industrial countries, particularly to the United States and Australia. However, there has emerged some signs of the resurgence to Asian economies in recent years. The annual size of such investment to Asian economies since 1993 has matched the sum invested in the United States and Europe(Table 1). These signs are even more obvious in agriculture, forestry, and fisheries, where the share of Asian economies has steadily risen to 51 percent in 1994 from only 14 percent in 1991.

The regional distribution of Japanese-affiliated firms (JAFs) in the foreign primary

Table 3. Regional Distribution of Japanese-affiliated Firms in the Foreign Primary Sector (ranked in order of share size)

\begin{tabular}{llrlr}
\hline \multicolumn{2}{c}{$1951-90$} & \multicolumn{2}{c}{$1991-95$} \\
\hline \multicolumn{2}{l}{ Total } & 100.0 & & 100.0 \\
\multicolumn{2}{c}{ Asian economies } & 37.7 & & 67.0 \\
1 & United States & 31.7 & China & 39.1 \\
2 & Thai land & 8.9 & United States & 13.5 \\
3 & China & 6.3 & Australia & 5.7 \\
4 & Brazil & 6.0 & Indonesia & 5.2 \\
5 & Australia & 5.8 & Thai land & 5.2 \\
6 & Chinese Taiwan & 4.4 & Hong Kong & 3.9 \\
7 & Singapore & 4.4 & Chinese Taiwan & 3.5 \\
8 & Indonesia & 3.0 & Singapore & 3.5 \\
9 & Hong Kong & 2.8 & Nether land & 3.0 \\
10 & Canada & 2.6 & Vietnam & 3.0 \\
\hline
\end{tabular}

Source: TOYO KEIZAI SHINPOSHA, Japanese Overseas Investment 1995,1996 (in Japanese). 


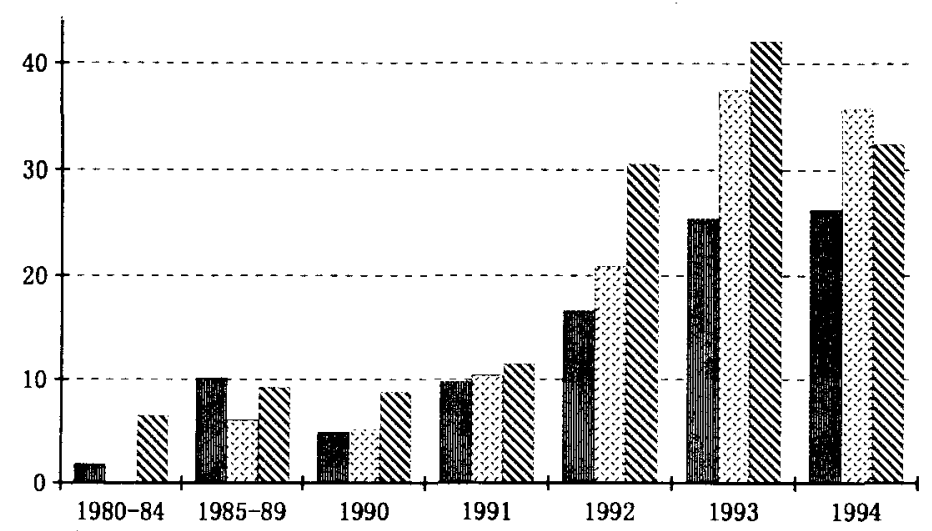

Fig. 1. China's shares in JDI flows to Asian economies (in percent) Source: Japan, Ministry of Finance Statistics Monthly.

明 Total Manufacture $\$$ Primary

sector may be able to suggest the direction of JDI flows. Table 3 indicates that nearly 38 percent of JAFs were located in Asia during 1951-90, but this share further rose to 67 percent in the last 5 years, implying that the JDI flows to the Asian primary sector are likely to be accelerated in the coming years.

The appearance of China as a new recipient of JDI flows since the mid-1980s has significantly contributed to the resurgence of JDI to Asian economies (Figure 1). In fact, China has rapidly become a leading recipient of these flows since 1990, receiving more than 30 percent of the investment into the Asian primary sector in the past 3 years. In 1995, China attracted 56 percent of JAFs in the foreign primary sector, and 67 percent of those in Asia, reflecting an increasing interest by Japanese investors in this country.

\section{DETERMINANTS OF JDI: AN APPROACH TO JDI FUNCTIONS}

Most observers tend to identify the determinants influencing direct investment flows from the capital recipients' side of the equation. The present study, however, attempts to do this by paying special attention to the capital-exporting side. This is because, in the international capital market, the capital-exporting side has been playing a dominant role in determining the direction and magnitude of capital flows, though this is also inevitably involved in the characteristics of the recipients' economies.

To explain the causes of the fluctuation of JDI flows over time and recent signs of the resurgence of such flows to Asian economies noted above, the following 6 factors are considered.

(1) Structural changes in food consumption and regulatory factors In order to meet the demand of diversified food consumption, the Japanese government has gradually expanded agricultural imports such as fruits, meat and vegetables since the early 1980s. The easing of regulations on food imports and the relaxing of restrictions on firm's import-oriented development accompanying the increase in the volume of 
agricultural imports can be regarded as having played important roles in driving JDI flows to the foreign primary sector.

(2) Business conditions and movement of the stock market Fluctuation in domestic business conditions and the stock market could have a large impact both on the profitability of firm activities and on the environment of a firm's capital financing. These are thus regarded as important factors in deciding whether a firm invests abroad.

(3) The firm's business strategies It is well known that foreign direct investment (FDI) is primarily driven by the expected investment-yields. Firms would, therefore, tend to invest in those countries with lower resource costs in order to obtain a competitive advantage within the industry. However, cost factors may not necessary be dominant when the firm's FDI decision is primarily based on consideration of long-term international business strategies.

(4) Structural changes in the agricultural sector Japan's agricultural structure, which is in general characterized by 'mini-sized land ownership and small-scale farming', has been further weakened since the mid-1980s, due to the rapid decrease of regular farm labor and the abandoning of cultivated land in rural areas. Some Japanese observers have argued that these changes in agricultural structure have exerted negative effects on the supply of some agricultural products that require much effort and, consequently, contributed to the expansion of JDI flows to the foreign primary sector through importoriented development. Of course, these changes themselves are also regarded as an outcome of increasing agricultural imports.

(5) Exchange rates It is reported that the price levels of principal agricultural products in Japan are significantly higher than that in most industrial countries. This gap has further been widened due to persistent decline of the Japanese yen against the U. S. dollar since the early 1980s. The stronger yen may have been a dominant factor driving private firms to invest in the foreign primary sector, particularly in Asian economies with lower-priced resources.

(6) Local factors in recipients' economies The high economic growth and marketoriented institutional reforms in some Asian economies such as China, have served as 'pull factors' to attract JDI flows. Moreover, sizable, low-developed markets, and low-priced resources in these economies make them more attractive as investment locations. The trend of the resurgence of JDI to Asian economies noted in the previous part may reflect an increasing attractiveness or credit-worthiness of these economies.

Although the above factors all are likely to be related to the movement of JDI flows, it is difficult to deal with them simultaneously in a model using only time-series data. Such capital flows are therefore hypothesized to be explained by the following model.

$$
\operatorname{Ln}(\mathrm{JDI})_{\mathrm{i}}=\beta+\delta \cdot \operatorname{Ln}(\mathrm{GRW})+\kappa \cdot \operatorname{Ln}(\mathrm{TSE})+\rho \cdot \operatorname{Ln}(\mathrm{YDR})+\varepsilon
$$

Where $\mathrm{i}=\mathrm{aa}$, sa, ap, sp, is regional and sectorial subscript, representing 'all countries, all industries', 'Asian economies, all industries', 'all countries, primary sector', and 'Asian economies, primary sector', respectively. In order to examine the differences on determinants of JDI between Asian economies and the others, these divisions may be useful. GRW indicates business conditions, measured by the real growth rate of Japan's GNP. TSE is The Nikkei Stock Average Index (TSE 225 Issues), indicating the changes in financial fundamentals over time, and to some extent reflecting an overall outcome of the 
changes in interest rates and, therewith, the response to domestic monetary policies such as fiscal adjustment. YDR is the ratio of the Japanese yen to the U. S. dollar, being viewed as a combination of some domestic and external factors described in (1), (3), and (4) above. GRW and TSE are normalized by 1990 figures, whereas YDR by 1971 figure, respectively. $\varepsilon$ is simply the error term; $L n(\cdot)$ denotes the natural logarithm. So, four models with a set of same independent variables should be estimated respectively.

Those factors noted in (6) are not taken into consideration in the above model because of unavailable data. Their contribution will be indirectly examined by the unexplained part by the three variables. Statistically, this kind of contribution can be estimated by the equations (2) or (3) below. As FDI flows are usually considered to be significantly sensitive to the local factors in recipients' economies, this approach might be imperfect. In this context, the following analyses will be employed together with firm survey data.

$$
\begin{aligned}
& \theta_{\mathrm{E}}=\mathrm{Ln}(\mathrm{JDI})-\left(\delta \mathrm{S}_{\mathrm{GKW}}+\kappa \mathrm{S}_{\mathrm{TSE}}+\rho \mathrm{S}_{\mathrm{YIN}}\right) \\
& \mathrm{S}_{\mathrm{GRW}}=[\mathrm{Ln}(\mathrm{GRW})-\overline{\mathrm{Ln}(\mathrm{GRW})}], \quad \mathrm{S}_{\mathrm{TSE}}=[\mathrm{Ln}(\mathrm{TSE})-\overline{\mathrm{Ln}(\mathrm{TSE})}], \\
& \mathrm{S}_{\mathrm{YDR}}=\left[\mathrm{Ln}(\mathrm{YDR})_{1}-\overline{\mathrm{Ln}(\mathrm{YDR})}\right] \\
& \theta_{\mathrm{E}}=\mathrm{dLn}(\mathrm{JDI})-[\delta \cdot \mathrm{dLn}(\mathrm{GRW})+\kappa \cdot \mathrm{dLn}(\mathrm{TSE})+\rho \cdot \mathrm{dLn}(\mathrm{YDR})
\end{aligned}
$$

Where $\overline{\operatorname{Ln}(\cdot)}$ denotes the average of $\operatorname{Ln}(\cdot)_{i}$.

\section{ESTIMATION AND EMPIRICAL EVIDENCE}

The estimates are reported in table 4, where generalized least squares (GLS) was used to estimate 4 regression equations for time-series annual data over the period 197094. The results of model (JDIaa) indicates that the three variables are able to account statistically for the variance well, and TSE and YDR are statistically significant at the 5 percent significance level, suggesting that JDI flows can substantially be explained by the

Table 4. Parameter Estimates for JDI Functions

\begin{tabular}{ccccc}
\hline & JDIaa & JDIsa & JDIap & JDIsp \\
\hline \multirow{2}{*}{ Constant } & -0.168 & 4.164 & 11.069 & 12.330 \\
& $(0.16)$ & $(1.65)$ & $(3.58)$ & $(3.86)$ \\
GRW & 0.205 & 0.753 & 0.111 & -0.751 \\
& $(1.65)$ & $(2.58)$ & $(0.31)$ & $(2.05)$ \\
TSE & 1.241 & 0.266 & 0.204 & 0.607 \\
& $(11.30)$ & $(1.02)$ & $(0.64)$ & $(1.87)$ \\
YDR & -0.526 & -1.190 & -2.228 & -2.223 \\
& $(2.85)$ & $(2.76)$ & $(4.21)$ & $(4.07)$ \\
$\bar{R}^{2}$ & 0.990 & 0.921 & 0.882 & 0.852 \\
$\mathrm{~F}_{3,2}$ & 833.8 & 94.8 & 60.8 & 46.9 \\
$\theta_{\mathrm{E}}(\%)$ & 27.9 & 26.6 & 33.7 & 47.8 \\
& & & & \\
\hline
\end{tabular}

Sources: Japan, the Ministry of Finance; Economic Planning Agency;

Tokyo Stock Exchange; IMF.

$\mathrm{t}$-statistic in parentheses. 
changes in the firm's financing environment and exchange rates. However, for model (JDIsa) GRW becomes statistically significant, while TSE is no longer significant at conventional levels, implying that the effect of domestic business fluctuation on JDI flows to Asian economies are more important than that of financial fundamentals, aside from exchange rates. Summarizing the two estimation results, it may be noted that the fluctuation of the aggregate JDI flows over time is primarily determined by exchange rates, firm's financing environment, and domestic business conditions. In other words, the movement of the aggregate JDI flows depends to a great degree on changes in domestic economic conditions.

However, the estimates of model (JDIap) and (JDIsp), which are used to analyze such flows to the foreign primary sector, are somewhat different from the above estimation results. Comparing the two results with the former two, we can find some distinquishable features. First, such capital flows to the primary sector are only sensitive to exchange rates YDR and no again respond to the other two variables in (JDIap). By contrast with this, YDR and GRW are statistically significant, but the sign of GRW is negative in (JDIsp), quite different from that in (JDlaa) and (JDIsa). Such flows to the primary sector then appear to have been driven primarily by the cost factors of agricultural products, as persistent recession has contributed to flowing to this sector of Asian economies with low-priced resources. Second, the absolute sizes of elasticities of YDR in (JDIaa) and (JDIsa) are 0.52 and 1.19, while those of (JDIap) and (JDIsp) are about 2.22. The investmwnt flows to the primary sector then are more sensitive to exchange rates related to the differences in product costs between domestic and agricultural product export countries than the aggregate JDI, supporting the foregoing explanation on cost determinants. Third, it is clearly that only three variables in the models are insufficient to explain the changes in JDI to the primary sector, particularly to those of Asian economies, because the sizes of adjusted- $\mathrm{R}^{2}$ are significantly lower, and the intercept terms become statistically significant, compared to the former two results.

The results of decomposition analyses based on equation (3) are displayed in the bottom row of table 4 . The unexplained part of such flows to the primary sector from the period 1985-89 to 1990-94 accounted for about 34 percent in the case of all countries, and 48 percent in Asian economies. So, some additional explanation based on firm survey data appears to be desirable.

The unexplained part of such flows to the primary sector can be caused by many factors, but the most important may be those in recipient economies, for example, changes in the investment climate involving investment yields and those related to the interdependence of intercountry economic activities. Table 5 presents some firm survey data where net income rates after taxes of JAFs are reported both on sales base and on capital stock base. The investment in Asian economies showed higher returns than that in other regions, which played a substantial role to cover the low efficiency in Europe, North America, and Oceania as well. These survey results may suggest different investment patterns of Japanese investors between Asia and other regions, and also provide some evidence for the estimation in table 4

A glance at JAFs' investment intentions may be useful in further examining the factors influencing the fluctuation over time and regional distribution of JDI flows, the questionnaire data from $4800 \mathrm{JAFs}$ is provided in table 6 . These survey results illustrate 
Table 5. Net Income Rates After Taxes of Japanese-affiliated Firms (in percent)

\begin{tabular}{|c|c|c|c|c|c|c|}
\hline & \multicolumn{2}{|c|}{$\begin{array}{l}\text { Agriculture, } \\
\text { forestry } \& \\
\text { fisheries }\end{array}$} & \multicolumn{2}{|c|}{$\begin{array}{l}\text { Food } \\
\text { processing }\end{array}$} & \multicolumn{2}{|c|}{$\begin{array}{l}\text { All } \\
\text { industries }\end{array}$} \\
\hline & $\mathrm{A}$ & B & A & $\mathrm{B}$ & $\mathrm{A}$ & $B$ \\
\hline All countries & -9.36 & -8.13 & 0.06 & 0.20 & -0.18 & -0.91 \\
\hline Asian economies & 0.75 & 2.45 & 2.58 & 8.67 & 1.89 & 12.08 \\
\hline China & 6.07 & 7.57 & 1.37 & 2.19 & 3.84 & 5.59 \\
\hline NIEs & 0.97 & 38.42 & 5.48 & 23.44 & 1.26 & 15.62 \\
\hline North America & -1.84 & 1.55 & -0.81 & -6.92 & -1.07 & -4.31 \\
\hline Europe(EU) & - & - & -3.01 & -17.82 & -0.55 & -6.32 \\
\hline Oceania & -9.28 & -9.02 & 4.90 & -14.64 & -0.88 & -6.47 \\
\hline
\end{tabular}

Source: MITI, Wagakuni Kigyo no Kaigai Jigyo Katsudo, 24th Report.

A: (Net income/Sales)*100, B: (Net income/Capital stock)*100

Table 6. Motives for Investing Abroad (in percent)

\begin{tabular}{|c|c|c|c|c|c|}
\hline & \multicolumn{2}{|c|}{ Cost factors } & \multicolumn{2}{|c|}{ Local market factors } & \multirow[b]{2}{*}{ Others } \\
\hline & $\begin{array}{l}\text { Using } \\
\text { local } \\
\text { resources }\end{array}$ & $\begin{array}{l}\text { Importing } \\
\text { to Japan }\end{array}$ & $\begin{array}{l}\text { Keeping } \\
\text { local } \\
\text { markets }\end{array}$ & $\begin{array}{l}\text { Long-term } \\
\text { business } \\
\text { strategies }\end{array}$ & \\
\hline \multicolumn{6}{|l|}{ Rates by region } \\
\hline All countries & 11.0 & 4.2 & 31.4 & 15.2 & 38.2 \\
\hline Asian economies & 16.1 & 6.4 & 28.2 & 16.6 & 32.7 \\
\hline China & 22.8 & 14.2 & 21.6 & 21.2 & 20.2 \\
\hline United States & 4.5 & 2.5 & 33.7 & 15.4 & 43.9 \\
\hline Australia & 13.9 & 2.0 & 34.7 & 10.2 & 39.2 \\
\hline Europe & 2.8 & 1.4 & 37.5 & 14.0 & 44.3 \\
\hline \multicolumn{6}{|l|}{ Rates by industry } \\
\hline All industries & 11.0 & 4.2 & 31.4 & 19.6 & 33.8 \\
\hline $\begin{array}{l}\text { Agriculture, forestry } \\
\text { \& fisheries }\end{array}$ & $\begin{array}{l}y \\
y\end{array}$ & 14.8 & 7.6 & 16.2 & 15.2 \\
\hline Food industry & 27.2 & 8.5 & 24.5 & 23.5 & 16.3 \\
\hline
\end{tabular}

Source: TOYO KEIZAI SHINPOSHA, Japanese Overseas Investment 1995 (in Japanese).

great differences, both between Asian economies and the other regions and between the primary sector and the average of all industries. It is obvious that Japanese investors have paid great attention to cost factors when they consider some Asian economies as investment locations, but in the case of other regions factors reflecting the interdependence of international economic activities such as the existing shares in local markets and information uses, appear to be given more attention. Comparing these of the primary sector with the average of all industries, cost considerations are found to account for over 60 percent in deciding whether to invest in foreign agriculture, forestry and fisheries, quite a high rate relative to the average. Although this kind of survey data would vary with world business conditions, it is undoubtedly the case that the differences 
in product costs between domestic and agricultural product export countries have been the dominant determinants influencing the distribution and magnitude of JDI flows to the primary sector. Moreover, the resurgence of JDI to Asian economies is presumably driven not only by an 'overseas investment boom', but also reflects to a certain degree Japanese investor's overall judgement for the local investment climate or credit-worthiness of the recipient economies in Asia.

From the above discussion, we may roughly feature JDI as two plausible types: a costreduction-seeking type relevant to the declining Japanese yen/U. S. dollar ratio and weakening domestic agricultural structure, and a market share-seeking type related to the interdependence of intercountry economic activities. Of course, the two types are not necessary exclusive reciprocally, and the former may, however, prove more suitable to explain the flows to Asia.

\section{SOME PROSPECTS ON THE RESURGENCE OF JDI FLOWS TO ASIA}

As discussed in parts 2 and 3, the issue of whether the resurgence of JDI to Asian economies can continue depends largely on the changes in the following 4 factors: (1) exchange rates and domestic agricultural structure; (2)domestic business conditions and firm's external financing environment; (3)local investment environment in recipient economies, particularly those involving product cost or investment yields; and (4)the interdependence of economic activities with recipient economies. Keeping these factors constant and, ceteris paribus, the size of JDI to the foreign primary sector as a whole may be expected to increase continuously.

The fact that JDI flows to the primary sector of Asian economies are influenced by not only domestic factors but also the factors uncontrolled by itself suggests that there is less reason to suppose a quick decrease of these flows in this region, though there are

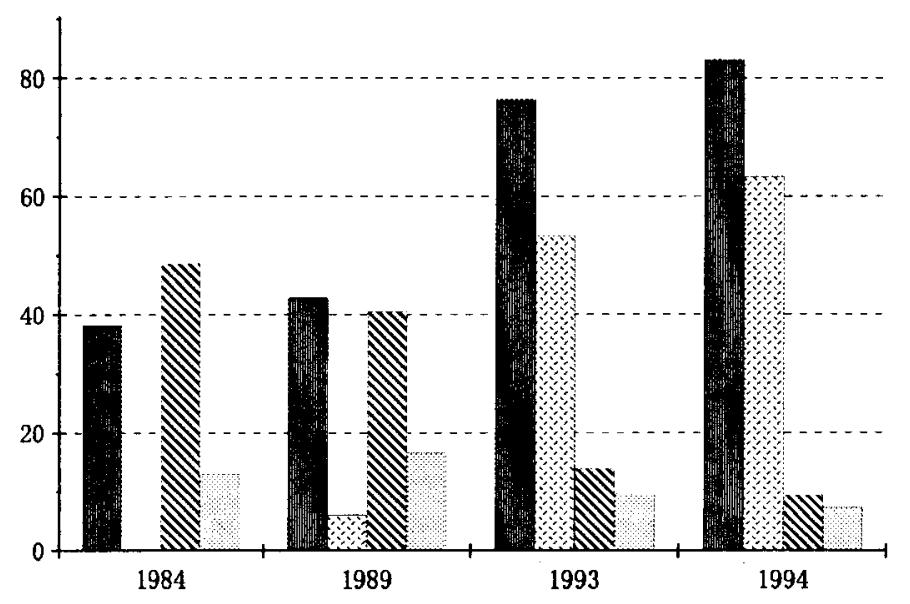

Fig. 2. Regional distribution of JDI cases from small and medium enterprises (in percent) Source: Japan, the Ministry of International Trade and Industry (MITI)
䀳留 Asia
China
$\mathbb{N}$ North-America
others 
some possibilities of transitory adjustment. Figure 2, which summarizes the changes in regional distribution of JDI cases from small and medium enterprises for selected years from 1984 to 1994, illustrates an increasing trend of investing in Asian economies, particularly China. For example, 83 percent of these enterprises were located in Asia, whereas China alone accounted for about 60 percent in 1994. A similar trend is also seen in the food industry. According to the most recent survey by the Ministry of Agriculture, Forestry and Fisheries in April 1996, over 70 percent of the surveyed food manufacturers showed a vigorous willingness to invest in Asian economies, especially China, Vietnam, Thailand and Indonesia, implying that Japanese investors may have seen these emerging recipient countries as the most favorable investment locations. It could be expected that the emerging of India, Vietnam, and Myanmar as new recipients of JDI flows would further contribute to this trend.

Nevertheless, there are also some uncertainable factors that are likely to disturb JDI flows to the primary sector of Asian economies from a medium- and long-term view. The willingness to invest abroad may decline because of the climbing ratio of the Japanese yen versus the $\mathrm{U}$. S. dollar. As indicated in part 3, a 1 percent change in the ratio would, ceteris paribus, generate about a 2 percent change in JDI flows to this sector. This willingness is also greatly influenced by some external factors such as recovery of economic activities in industrial countries, the emergence of new recipients other than Asia, and, of course, possible changes in the investment climate of Asian economies. For example, unstable economic policy in recipient economies may lead to FDI reversals or firm withdrawing from those economies. Moreover, as there has been concern about the effects of increasing import-oriented development on domestic agricultural structure, the Japanese government's response may produce some indirect influences on the direction and magnitude of JDI flows to the foreign primary sector.

\section{CONCLUSIONS}

JDI to foreign primary sector as a whole have been rapidly increased since the mid1980s. These investment flows, recently, are largely concentrated in Australia, the United States and some economies in Asia. However, there has emerged some signs of reflowing to Asian economies since the beginning of 1990s. Over half of the Japanese firms investing in this sector have been attracted by Asian economies, particularly China. The appearance of China as a new recipient of such capital flows since the mid-1980s has substantially contributed to the resurgence of JDI to Asia.

JDI flows are largely influenced by exchange rates and domestic agricultural structure, domestic business fluctuation and firm's external financing environment, cost factors, and the interdependence of economic activities with recipient economies. Cost factors appear to have played a dominant role in driving the flows to the primary sector of Asian economies.

Japanese investors shows a great interest in investing in Asia, suggesting that JDI flows to the primary sector of this region are likely to increase continuously in the coming years. However, as the flows are very sensitive to exchange rates, domestic agricultural structure, and the change in local cost factors in recipient side, fluctuation will be inevitable. 


\section{REFERENCES}

Barasubramanyan, V. 1984 Incentives and disincentives for foreign direct investment in less developed countries, Weltwirtschaftliches Archiv 120: 720-735.

Eduardo Fernandez-Arias and Peter J. Montiel 1996 The surge in capital inflows to developing countries: an analytical overview, The World Bank Economic Review 10(1): 55-77.

Grubaugh, S. G., 1987 Determinants of direct foreign investment," Review of Economic and Statistics 69 149-152.

IMF 1985 Foreign private investment in developing countries, Occasional Paper 33 Washington.

Jackman, R. W. 1982 Dependence on foreign investment and economic growth in the Third World, World Politics 34: 175-196.

Mohsin S. Khan and Carmen M. Reinhart 1995 Capital flows in the APEC region, IMF, Occasional Paper 122, Washington.

Schneider, F. and Frey, B. S. 1985 Economic and political determinants of foreign direct investment World Development 13: 161-175.

T. Saito 1992 Foreign direct investment of Japanese food industries: adjusting to the global economy, National Research Institute of Agricultural Economics, Tokyo, Japan (in Japanese). 